\title{
Precipitation cycles in Turkey
}

\author{
Erkan Yılmaz ${ }^{1}$ (D) $\cdot{\text { Yılmaz } \text { Akdi }^{2} \cdot \text { Esra Uğurca }^{2} \text {. Ihssan Çiçek }}^{1} \cdot$ Cemal Atakan $^{2}$
}

Received: 23 July 2018 / Accepted: 30 November 2020 / Published online: 5 January 2021

(C) The Author(s) 2021

\begin{abstract}
Turkey is located in the temperate zone; thus, it is influenced by regionally different air masses during summers and winters, resulting in different precipitation regimes. Often, systems with varying masses of air repeatedly affect Turkey; however, at times, these periods are disrupted and difficult to predict. This study analyzes whether a certain periodicity exists in the seasonal and annual total precipitation of 74 meteorological stations in Turkey using periodograms. The analyses conducted herein showed more than one period in the series; therefore, this study was extended, and the first six periods were examined. As a result, we found 2-, 3-, 4-, and 5-year precipitation cycles (PCs) in the short term; 6-, 7-, and 8-year PCs in the medium term; and 11-, 12-, 14-, 17-, and 21-year PCs in the long term in Turkey's PC. While seasonal distributions exhibited similarities, there were significant differences in the seasonal frequencies owing to seasonal variations in the systems affecting Turkey. The cycles vary by region, and some of these cycles can be found in each region. Three cycles have been identified in Turkey according to frequency and length, namely: (1) short-term cycle across Turkey; (2) Eastern and Central Anatolia, the Black Sea, and Aegean regions; and (3) borders of Central Anatolian and the eastern Mediterranean region. A cluster identifies unrelated locations as the affected local factors. Cycles are connected to the NAO, whereas solar activity is observed throughout Turkey. The analysis showed that certain cycles were repeated and were not dominant in each period, with the best example of this cycle as the 7-1421 consecutive cycles.
\end{abstract}

\section{Introduction}

Climatic systems comprise several components, including the locations of air mass centers that change based on the energy balance, ocean currents, large land cover changes, and glacial melting, as well as effected changes in the ocean surface water

Erkan Y1lmaz

eryilmaz@ankara.edu.tr

Y1lmaz Akdi

akdi@ankara.edu.tr

Esra Uğurca

esrasys@gmail.com

İhsan Çiçek

ihcicek@ankara.edu.tr

Cemal Atakan

catakan@ankara.edu.tr

1 Faculty of Language, History and Geography, Department of Geography, Ankara University, 06100 Ankara, Sihhiye, Turkey

2 Faculty of Science, Department of Statistic, Ankara University, 06100 Ankara, Tandoğan, Turkey temperature and other atmospheric feedbacks. Volcanic eruptions, plate tectonics, and the solar activity also influence the climate system. Some of these effects can be regularly recurring events, cases, or circumstances defined as cycles or periods. Milankovitch cycles, which occur in eccentricity, obliquity, and precession, are well-known periodic and predictable cycles (van den Heuvel 1966; Kerr 1987; Muller and Macdonald 1997; Rial 2004) that have led to the formation of the Pleistocene glacial periods. Several meteorological variables have been measured since 1850, which is an instrumental period in climatology, and their records have been maintained. These documents have now achieved an extremely high temporal resolution. Shorter periods that are not long term, such as Milankovitch cycles, can be investigated using the data obtained from climate variable measurements recorded during this period. The time series generated from the proxy records are also used to determine longer cycles. These are then combined to provide and control the climate formation in a field. Some of these components randomly occur on a temporal scale; however, some of these components are repeated in a certain analysis of the time series obtained from various sources globally. Accordingly, cycles having varying lengths are determined. Although they differ 
in regional differences, they also exhibit certain similarities. Table 1 presents a regional literature review of periodicity.

Various lengths can be identified during an assessment of cycles; however, some of these are not measured in years. Short-term annual cycles vary from 2 to 5 years and are connected to atmospheric oscillations such as North Atlantic Oscillation (NAO) and El Niño-Southern Oscillation (ENSO). Some cycles in these oscillations may be semiperiodic. Although an actual cause of these cycles has not yet been identified, the 7-8-9-year cycles have been found to be associated with atmospheric oscillations, patterns, teleconnections, and current systems. Moreover, the 11- and 22-year cycles have been identified in many time series and proxy data associated with solar activities. Furthermore, 35-, 50-, 100-, 220-, 512-, 600-, and 800-year cycles are observed to be long term. These cycles depend on changes in solar activity, the thermohaline system, and Milankovitch cycles.

The seasonal cycles in Turkey's precipitation data were analyzed by Türkeș et al. (2002) and Türkeș (1998, 1999). They determined 8.4-, 12-12.7-, 14-, 18-, and 21-year cycles for winter, 2-, 3-, 4-, and 5-year cycles for the spring and summer seasons, and 2-, 3-, 4-, 5-, 8.4-, 10.5-, and 21-year cycles for autumn. Türkeş et al. (2002) repeated the same analyses for 500-hPa geopotential height patterns, and except for the summers, similar results with seasonal periods were revealed. However, they did not examine the annual periods

Table 1 Cycle studies in climatology based on literature

\begin{tabular}{|c|c|c|c|c|}
\hline & Region & Cycle length & Data sources & Reference \\
\hline \multirow[t]{6}{*}{ S. Amerika } & Maya Lowlands & $39,50,100,208$, and 810 & Oxygen isotope series & Hodell et al. (2001) \\
\hline & The Monsoon cell & 84,102 , and 775 & Marine sediments & Wang et al. (1999) \\
\hline & & 208 and 514 & & \\
\hline & Anatolia & 208 and 514 & Erosional deposits & Fairbridge et al. (1997) \\
\hline & Andes & $500-600$ & Pollen & Bush et al. (2005) \\
\hline & S. America & 800 & Speleothem & Strikis et al. (2011) \\
\hline \multirow[t]{5}{*}{ N. Amerika } & Canada & $0.7,2.7$, and $3.3 \mathrm{y}$. & Drought & Asong et al. (2018) \\
\hline & Platte River & 4,5 and 6,7 & Discharges & Daniels (2007) \\
\hline & California & 22 & Speleothem & Mccabe-Glynn et al. (2013) \\
\hline & N. America & 3 & Drought & Hunt (2016) \\
\hline & N. America & 256 and 512 & Diatom analyses & Stager et al. (2017) \\
\hline \multirow[t]{3}{*}{ Africa } & East Africa's & $2,2.5,3.5$, and 5 & Rainfall data & Rodhe et al. (1976) \\
\hline & Niger & 2 & Drought & Abdourahamane and Acar (2018) \\
\hline & South Africa & 7.6 & Rainfall & McHugh and Rogers (2001) \\
\hline \multirow[t]{8}{*}{ Asia } & Handan (China) & 5,9 & Rainfall & Luan et al. (2009) \\
\hline & China & $2.1,2.7,3.5,7.2$, and 9 & Tree rings & Hughes et al. (1994) \\
\hline & N China & 8 and 13 & Drought & Fang et al. (2018) \\
\hline & Central Chinese & $6,10.3,14,34.6,117$, and 8 & Speleothem & Tan et al. (2009) \\
\hline & Korea & 5,14 , and 33 & Droughts & Kim and Byun (2010) \\
\hline & Central Asia & 1.3 and 5.3 & Droughts & Guo et al. (2018) \\
\hline & Mongolia & 3,4 , and 22 & Tree rings & Jacoby et al. (2003) \\
\hline & W. Himalayan & 2 & Tree rings & Singh et al. (2006) \\
\hline \multirow[t]{11}{*}{ Europe } & Scotland & $2-4,4-7$, and $1-24$ & Rainfall & Afzal et al. (2014) \\
\hline & Czech Republic & $3.4,3.5,4.2,5,5.1$, and 15.4 & Drought & Brázdil et al. (2009) \\
\hline & Europe & $2,3,4,5$, and 13 & Rainfall & Brázdil et al. (1985) \\
\hline & Spain & $0.09,0.16,0.3$, and 1 & Rainfall & Lázaro et al. (2001) \\
\hline & Belgrade, Serbia & $6,7,10-18,21,31$, and 41 & Rainfall & Vujović et al. (2018) \\
\hline & Adriatic Sea & 5.5 and 7.3 & Zooplankton & Baranovic et al. (1993) \\
\hline & Zagreb & $2-6$ and $16-34$ & Rainfall & Gajic-Capka (1992) \\
\hline & Croatia & $2.2,4.7,25,33$, and 3 & Rainfall & Gajić-Čapka (1994) \\
\hline & Italy & $2-2.8,3-4,7.5-8.5$, and $14-26$ & Rainfall & Brunetti et al. (2000) \\
\hline & Mediterranean & $3-5,9,11-13,20-27$, and $50-100$ & Marine sediments & Manzi et al. (2012) \\
\hline & Iber Peninsula & $2-3$ and $5-6$ & Rainfall & Merino et al. (2015) \\
\hline \multirow[t]{6}{*}{ Oscillations } & NAO & $10-20$ & NAO index & Polonskii et al. (2004) \\
\hline & NAO & $2-6$ & NAO index & Zhang et al. (2011) \\
\hline & SO and IOD & $3.5-5.2$ & Index & Ashok et al. (2003) \\
\hline & $\mathrm{SO}$ & $2-4$ & Index & Jin and Kirtman (2010) \\
\hline & El-Nino & $2.1,2.8,4.1$, and 6.3 & Index & Davies et al. (2012) \\
\hline & QBO & 1.3 and 1,8 & Index & $\begin{array}{l}\text { Baldwin et al. (2001); Pascoe } \\
\text { et al. (2005) }\end{array}$ \\
\hline \multirow[t]{2}{*}{ Sunspots } & & 11 & Sunspots & Arlt (2011); Hathaway (2015) \\
\hline & & 22 & Sunspots & $\begin{array}{l}\text { Lean and Rind (1998); Mursula } \\
\text { et al. (2002) }\end{array}$ \\
\hline
\end{tabular}


and performed the analysis using an autocorrelation function and the spectral method. Periods up to one-third of the number of years of data used may be calculated based on the method used. Notably, some discussions on the causes of cycles have not been compared with the cycles in other studies. Rainfall cycles are critical in understanding precipitation systems and making future predictions. Herein, the periodogram method is used rather than the previously used methods. Furthermore, similarities with other studies are determined, whereas the data set is extended by repeating and interpreting the analyses. Therefore, we analyzed the following questions and discussed the findings using periodograms and time-series analyses:

- Are there any cycles in the seasonal and annual precipitation in Turkey? If so, do these cycles have the same length for the whole of Turkey?

- How many PCs exist in Turkey? Do they differ by region? Is there a regionalization involved in these cycles?

- Do the cycles have a logical relationship with oscillations, patterns, and teleconnections compared with the global climate system?

\section{Data and method}

\subsection{Data used in the present study}

Monthly precipitation data of 74 stations (measuring at least 65 years) between 1926 and 2014 are obtained from the Turkish General Directorate of Meteorology and analyzed, as shown in Fig. 1. The missing values were determined, and the station with at most 1 -year missing values was selected. The missing values were filled using an arithmetic mean method (Enders 2010, p. 41). The period for determining the analysis was used. The stations were semiregularly distributed across Turkey and were located at an altitude of up to $1800 \mathrm{~m}$ above sea level. While 14 of the stations used herein are in the Black Sea Region, eight are in the Marmara Region; seven are in the Aegean Region; six are in the Mediterranean Region; 13 are in the Central Anatolia Region; 14 are in the Eastern Anatolia Region; and eight are in the Southeastern Anatolia Region (Fig. 1).

The seasonal time series were obtained by add up the rainfall of December, January, and February for winters; March, April, May for springs; June, July, and August for summers; and September, October, and November for autumns.

\subsection{Method}

A periodogram is a power tool that is generally used to analyze the possible periodicities in time series (Wei 2006, p. 289). Okkaoğlu et al. (2020) used a method to explore possible periodic components in the $\mathrm{PM}_{10}$ series in London using periodogram ordinates. A similar approach was also used for the precipitation data of Turkey.

Performing a periodogram-based analysis has many advantages. Fuller (1996), Wei (2006), Brockwell and Davis (1987), and Akdi and Dickey (1998) noted the following advantages of using a periodogram-based analysis: (i) the periodograms are calculated via trigonometric transformations without depending on any model specifications, and the method is

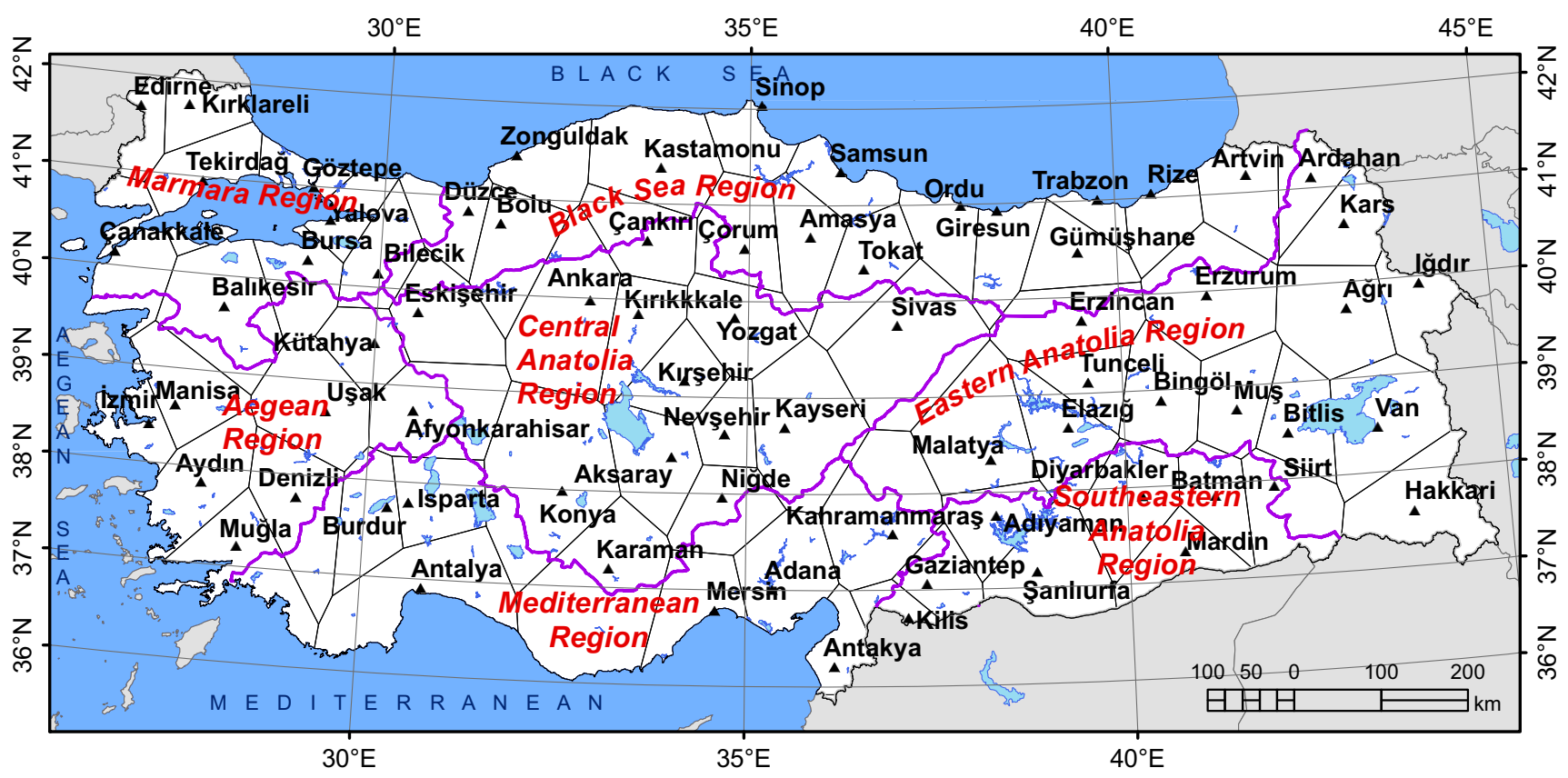

Fig. 1 Distribution of stations used in the analysis using geographical regions 
invariant to the mean; (ii) the fact that the critical values of the distribution do not depend on the sample size provides more efficient estimates for small samples; (iii) there is no need to estimate any parameters other than the variance of the white noise series; (iv) the analytical power function exists for the test because the normalized periodogram is asymptotically distributed as $\chi^{2}$ with two degrees of freedom under the alternative hypothesis; and (v) the results appear robust if the data have periodic components.

We consider the harmonic regression expressed as follows to explore possible periodic components in the data:

$Y_{t}=\mu+a \cos \left(w_{k} t\right)+b \cos \left(w_{k} t\right)+e_{t}, t=1,2, \ldots, n$.

The series contains a periodic component if the null hypothesis of $H_{0}: a=b=0$ is rejected. The hypothesis seems to be tested using the $F$ test; however, the frequency $w_{k}$ is unknown. Thus, the $F$ test may not be appropriate (Wei 2006), and a test statistic is defined to verify the possible periodic component in the data:

$V_{i}=I_{n}\left(w_{(i)}\right)\left[\sum_{k=1}^{m} I_{n}\left(w_{k}\right)-\sum_{s=1}^{i-1} I_{n}\left(w_{(s)}\right)\right]^{-1}$

The period corresponding to the $i^{\text {th }}$ maximum periodogram value is significant if $V_{i}>c_{\alpha}$. The critical values are calculated as $c_{\alpha}=1-(\alpha / m)^{1 /(m-1)}$. The period corresponding to the $i^{\text {th }}$ maximum periodogram value is significant if $V_{i}>c_{\alpha}$ (Wei 2006), where $\alpha$ refers to a significance level.

As a result of the analyses, it is verified whether the period at eachvalue is significant. While the existing period is determined for a series with a single period, it is necessary to advance the test when more than one period exists. In conclusion, starting from the maximum value, the periods are subjected to the hypothesis test, and it is verified whether there is a periodic component in the series. In certain cases, the periodic components determined have been found in decimal. Results showed that this method calculated the period frequency in the data and did not define the period length; thus, the period lengths could be used to remove their decimals.

The series must be stationary in such a way that the analysis can be performed. The stability of the time series used in the study was examined by increased Dickey-Fuller, PhillipsPerron, and stability tests based on periodograms. In addition to the standard unit root tests, the unit test based on periodograms proposed by Akdi and Dickey (1998) was also used, and the series was found to be stable. All the studied series were stationary at a 5\% significant level. Thus, no structural breakage occurred in the series, and a homogeneous structure was observed.

As a result of the analysis, some of the cycles provided the length of the number of years of data used, which is understood to be an insignificant cycle in the series. The cycles obtained were interpreted as short- ( $2-5$ years), medium- (610 years), and long-term (11+ years) periods.

Cluster analysis (Manly 2004) was used to determine similar cycle regions in which 3-6 cluster analyses were repeated and their results were mapped for comparison.

\subsection{Mapping and graphing of the results}

As a result of the periodogram-based hypothesis testing, each station's annual, winter, spring, summer, and autumn seasons cycles were determined. The most dominant cycle in the seasonal and annual values for each station was the highest. In addition, more than one significant cycle can be calculated. From this point of view, it is always possible to obtain $n / 2$ cycles for each station; however, not all of them were statistically significant. The meaningful cycles that can be used in this analysis can be evaluated based on the probability value. The analysis showed an extremely high significance value with a $p$ value of 0.05 , which was reduced owing to multiple cycles in the series. In this case, any cycle is disguised and hidden by other cycle effects. A cycle of up to a certain $k$ value is required to determine the cycles; therefore, the cycles should be examined for each station up to a certain $k$ value. No specific acceptance has been mentioned in the literature on this subject, and no information pertaining to the same is available. If all stations are examined together during this study, using a certain number of standard cycles would make the study feasible. Six cycles could be mapped through an intensive analysis of the obtained results. Meaningless and erroneous results can be obtained for mapping other cycles. Hence, a maximum of six periodogram values was used to emphasize the usability of the method in finding sub-cycles. The highest six values for each season and the annual cycle have been determined. Moreover, mapping and analysis were performed.

The annual period obtained as the analysis result at each value was written on the station during mapping. In addition, the result of the hypothesis test performed for the period was expressed by coloring the Voronoi polygon of the station.

\section{Results}

\subsection{Winter}

The 2-, 4-, and 8-year PCs in the Black Sea Region (BSR); 6and 8-year PCs at the stations in the Marmara Region (MAR); 8- and 17-year PC in the Aegean Region (AR); 2- and 3-year PCs in the Mediterranean (MR) and Central Anatolia (CAR) regions; 2-year PC in the Southeastern Anatolia Region (SAR); and 2- and 8-year PCs in the Eastern Anatolia Region (EAR) were repeated more according to the highest $I_{n}\left(w_{k}\right)$ values for winter. Most of the PCs obtained by the 
highest value could not exceed $p \leq 0.3$ limit, and the limit at different levels could be reached at some stations in the EAR and SAR, as shown in Fig. 2a.

The 2-6-, 8-, and 17-year PCs in the BSR; 2-4-, 7-, 8-, 14-, and 21-year PCs in the MAR; 2-, 3-, 6-8-, 14-, and 21-year PCs in the AR; 2-4-, 7-, and 8-year PCs in the MR; 2-, 3-, 6-, 7-, 8-, and 11-year PC in the CAR; 2-4-, 6-, 8-, and 9-year PC in the EAR; and the 3-, 6-, and 11-year PC in the SAR became frequent based on $I_{n}\left(w_{k}\right)$ values, as presented in Fig. $2 \mathrm{~b}-\mathrm{f}$. The 3 rd to 6 th values are significant for $p \leq 0.2$ level, whereas the second highest value is significant only for $p \leq 0.3$ level, as shown in Fig. 2f.

\subsection{Spring}

As a result of the analyzed time series of spring precipitation, the 2-, 3-, 5-, and 6-year PCs in the BSR; 4-year PCs in the MAR; 3- and 4-year PCs in the AR; 2- and 3-year PCs in the MR and CAR; and 2- and 4-year PC in the EAR and SAR
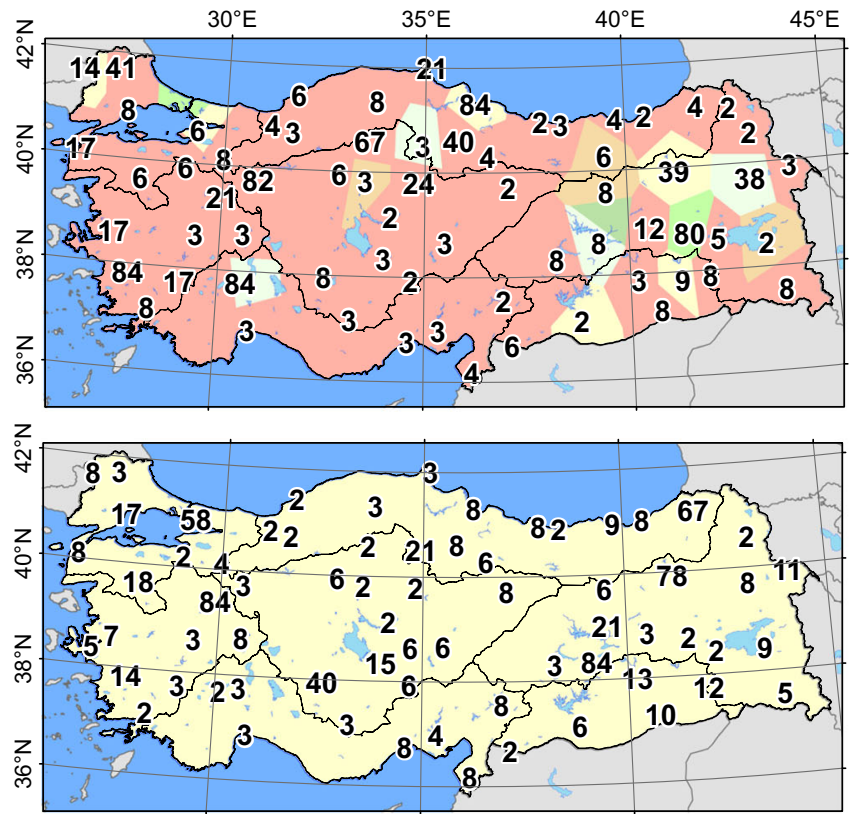

ชั

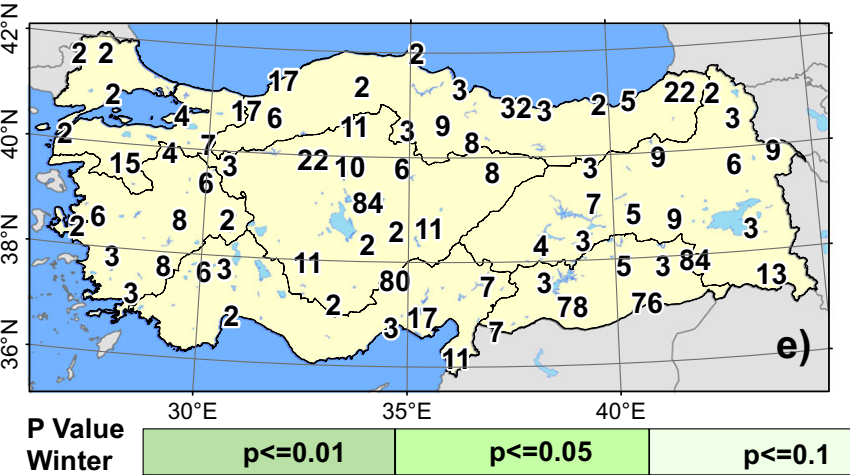

were determined for a highest value. The periods are significant for $p \leq 0.2$ and $p \leq 0.05$ levels in some parts of the MR, western and central BSR, MR, and EAR, as presented in Fig. $3 \mathrm{a}$.

In the highest value, the 2-5-, 8-, 12-, and 17-year PCs in BSR; 2-4-year PCs in MAR, AR, and EAR; 3- and 4-year PCs in MR; 2-4- and 6-year PCs in CAR; and 2-4- and 28year PCs in SAR are determined at the 2nd to the 6 th $k$ values, as shown in Fig. 3b-f. Similar to the winter period, the 2nd period showed $p \leq 0.3$, and the 3 rd to 6 th periods exhibited for $p \leq 0.2$ significance level.

\subsection{Summer}

In summers, 2-, 3-, 4-, and 5-year PCs in the BSR; 3- and 4year PCs in the MAR; 3-year PCs in the AR; 2- and 5-year PCs in the MR; 2-, 3-, and 6-year PCs in the CAR; 2-, 3-, 4-, and 5-year PCs in the EAR; and 11-year PCin the SAR were determined for the highest $I_{n}\left(w_{k}\right)$ value. The 5-year PC in the
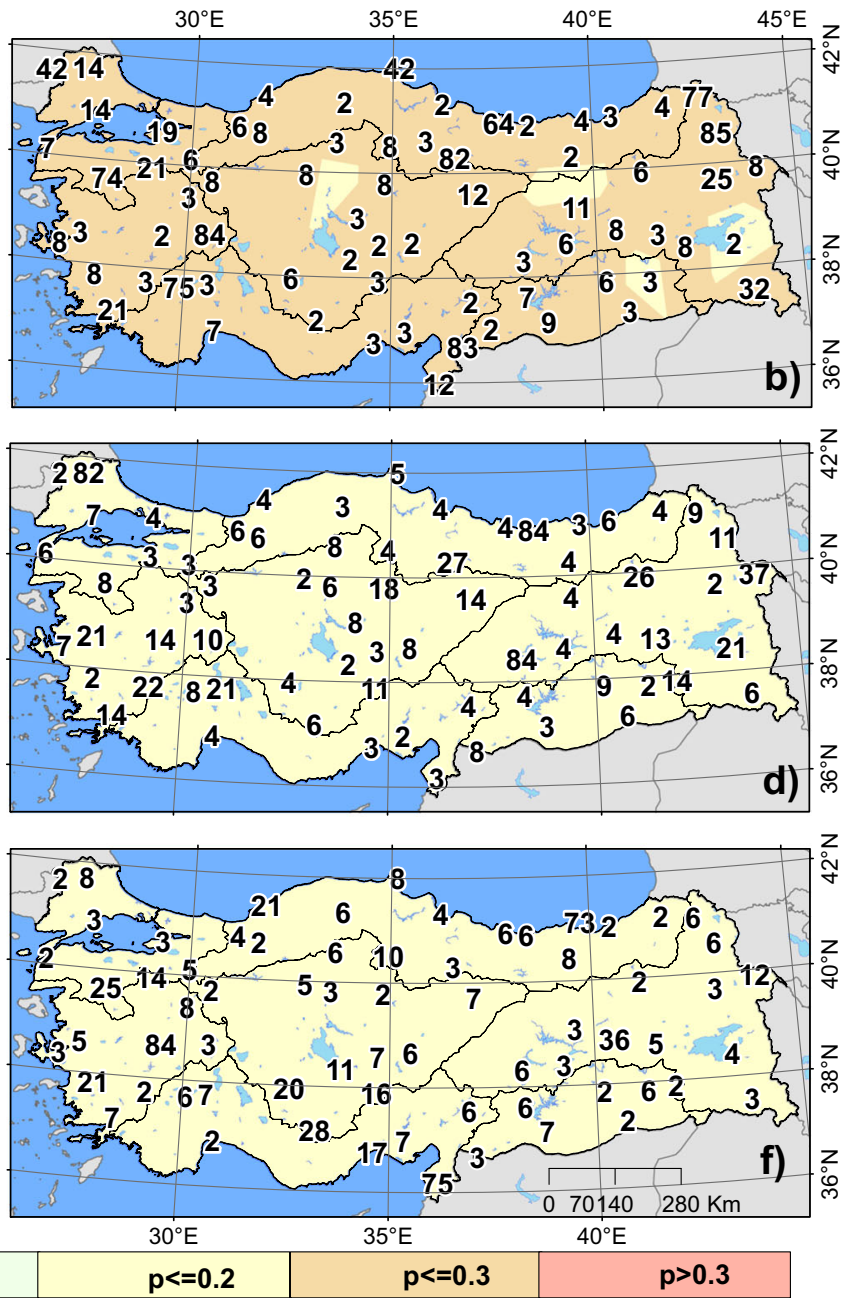

Fig. 2 a) PC map of highest $I_{n}\left(w_{k}\right)$ values, b) PC map of 2nd highest $I_{n}\left(w_{k}\right)$ values, c) PC map of 3rd highest $I_{n}\left(w_{k}\right)$ values, d) PC map of 4th $\mathrm{I}_{\mathrm{n}}\left(\mathrm{w}_{\mathrm{k}}\right)$ values, e) PC map of 5 th highest $\mathrm{I}_{\mathrm{n}}\left(\mathrm{w}_{\mathrm{k}}\right)$ values, f) PC map of 6 th $\mathrm{I}_{\mathrm{n}}\left(\mathrm{w}_{\mathrm{k}}\right)$ values 


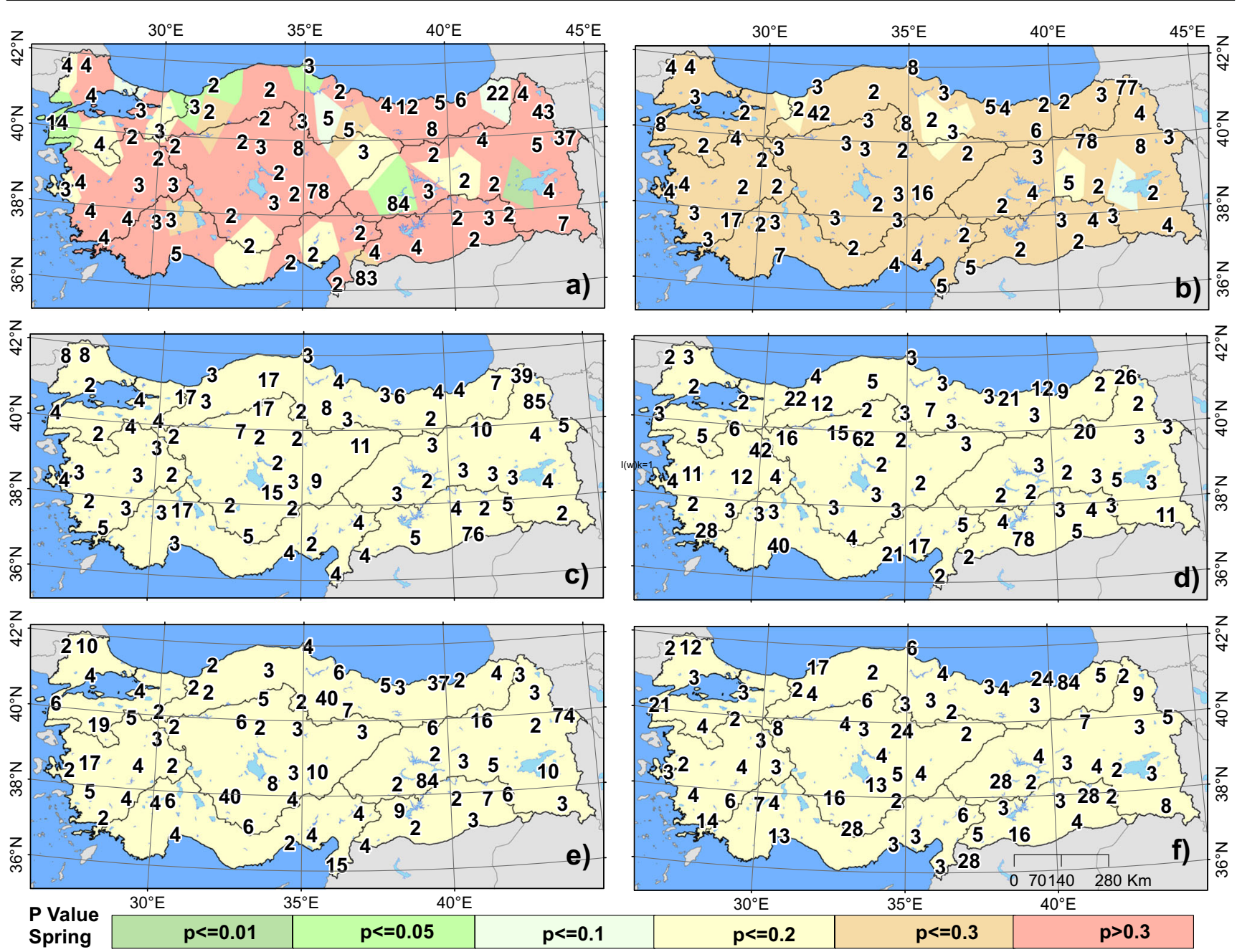

Fig. 3 a) PC map of highest $I_{n}\left(w_{k}\right)$ values, b) PC map of 2 nd highest $I_{n}\left(w_{k}\right)$ values, c) PC map of 3rd highest $I_{n}\left(w_{k}\right)$ values, d) PC map of 4th $I_{n}\left(w_{k}\right)$ values, e) PC map of 5 th highest $I_{n}\left(w_{k}\right)$ values, f) PC map of 6 th $I_{n}\left(w_{k}\right)$ values

BSR, 6-year PC in the CAR, and 11-year PC in the SAR are significant for $p \leq 0.05$ level, as shown in Fig. 4a.

Following the analysis of the 2nd to 6th values, 2- and 6year PCs in the BSR; 2-6-year PC in the MAR; 2-5- and 12year PCs in the AR; 2-, 3-, 6-, and 8-year PCs in the MR; 2-7year PC in the CAR; 2-5-, 21-, and 28-year PCs in the EAR; and 2-, 3-, 5-, and 6-year PCs in the SAR are determined at multiple stations, as presented in Fig. 4b-f. The significance levels were the same as those recorded in winters.

\subsection{Autumn}

The 2-4-year PC in the BSR, 2-4-year PC in the MAR, and 28-year PC in the AR were determined at multiple stations based on highest value during autumns. While different periods were obtained at all stations in the MR, 2- and 4-year PCs in the CAR and 2- and 3-year PCs in the EAR and SAR are determined (Fig. 5a). The periods were significant for $p \leq$ 0.05 and $p \leq 0.01$ levels; however, in some situations, the $p \leq$
0.1 level was observed to exceed, and a significance level was achieved for $p>0.3$ at the majority of stations.

When the analysis was repeated at 2 nd to 6 th highest values, 2-4-, 6-, and 8-year PCs in the BSR; 2-5- and 6year PCs in the MAR; 3-, 4-, 6-year PCs in the AR; 2-5-year PC in the MR; 2-5-, 7-, 9-, and 21-year PCs in the CAR; 2-4-, 6-, and 21-year PCs in the EAR; and 2-4-, 9-, and 26-year PCs in the SAR are observed at more than one station, and the vast majority of the periods exhibits a significance value for $p \leq 0.2$ level, as shown in Fig. 5b-f.

\subsection{Annual analysis}

For a total annual precipitation data, the 2- and 3-year PCs in the BSR; 2-, 3-, and 4-year PCs in the MAR; 17-year PC in the AR; 7-year PC in the MR; 2-, 11-, and 15-year PCs in the CAR; 2- and eight-year PCs in the EAR; and 5-year PC in the SAR were determined at multiple stations. While most of these PC could not exceed the $p \geq 0.3$ level, some are 


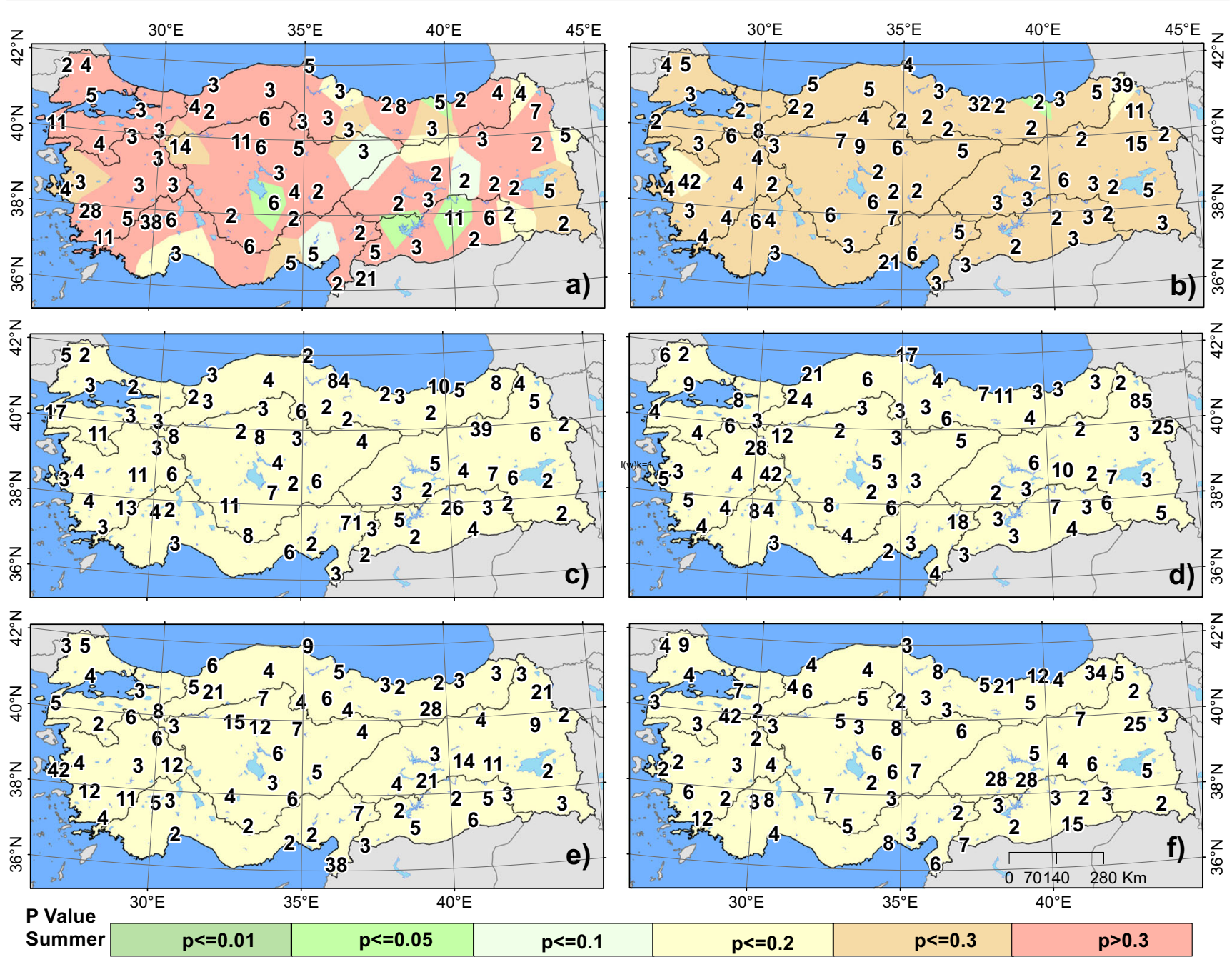

Fig. 4 a) PC map of highest $I_{n}\left(w_{k}\right)$ values, b) PC map of 2nd highest $I_{n}\left(w_{k}\right)$ values, c) PC map of 3rd highest $I_{n}\left(w_{k}\right)$ values, d) PC map of 4th $I_{n}\left(w_{k}\right)$ values, e) PC map of 5th highest $I_{n}\left(w_{k}\right)$ values, f) PC map of 6 th $I_{n}\left(w_{k}\right)$ values

significant for $p \leq 0.2, p \leq 0.1$, and $p \leq 0.05$ levels, as shown in Fig. 6a.

The 2-5-, 8-, and 42-year PCs in the BSR; 2-, 3-, and 14year PCs in the MAR; 3-, 4-, 8-, 14-, and 21-year PCs in the AR; 2- and 3-year PCs in the Mediterranean Region; 2- and 7year PCs in the CAR; 2-6- and 21-year PCs in the EAR; and 3-, 4-, and 6-year PCs in the SAR were determined at more stations based on the 2 nd to the 6th highest $I_{n}\left(w_{k}\right)$ value. Most of the PC at 2nd value exhibits a significance value for $p \leq 0.3$ level (Fig. 6b-f). The 3rd and 6th values exhibit for $p \leq 0.2$ significance level.

\section{Discussion}

Turkey is seasonally affected by different air masses. In winters, the 2- and 3-year PCs in the short term; 6- and 8-year PCs in the medium term; and 11-, 14-, 17-, and 21-year PCs in the long term are determined at several stations when the PC frequency was examined (Fig. 7). Similar results were obtained in the analysis by Türkeș (1998) and Türkeș et al. (2002), who reported 12- and 12.7-year PCs for the medium term. Herein, the cycle was characterized by an 11-year PC. Herein, the 18-year PC determined by Türkeș et al. (2002) was defined 17-year PC in this study. During winters, Turkey is frequently affected by midlatitude depressions originating from the Atlantic through the Balkans or Mediterranean paths (Türkeș 2010:450), resulting in humid and rainy weather conditions. At the same time, Asia has a strong influence on Turkey (Koçman 1993:3) and triggers cold and dry conditions. Although the Asor High is less effective in this season, it controls the impact rate of Turkey's midlatitude depressions. When it weakens, the amount of rainfall in Turkey increases, while drought conditions appear when it is strengthened.

The 2-, 3-, and 4-year PCs in the short term; 8-year PC in the medium term; and 16- and 17-year PCs are obtained in several stations in spring, as shown in Fig. 8. The 2-5-year 


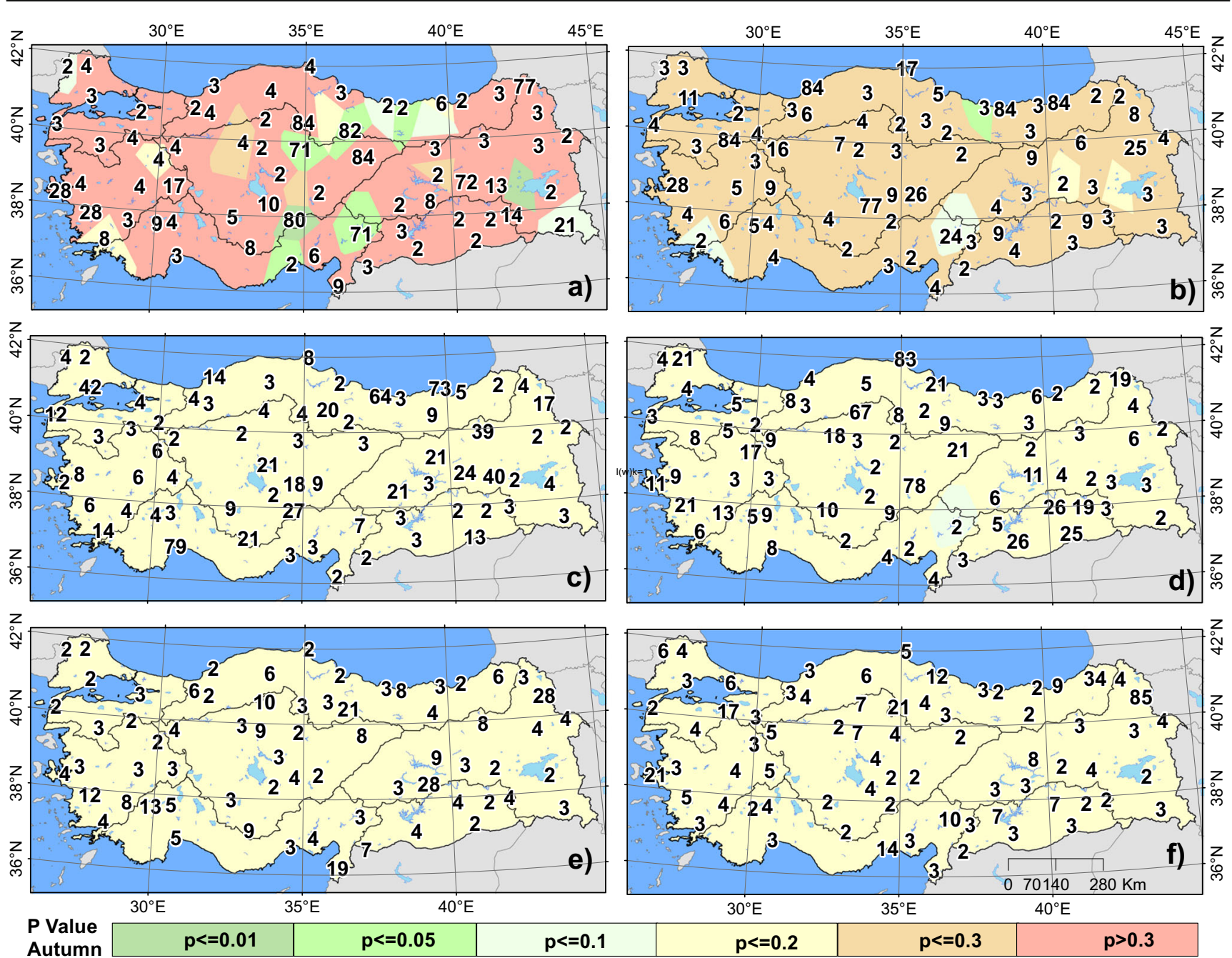

Fig. 5 a) PC map of highest $I_{n}\left(w_{k}\right)$ values, b) PC map of 2 nd highest $I_{n}\left(w_{k}\right)$ values, c) PC map of 3rd highest $I_{n}\left(w_{k}\right)$ values, d) PC map of 4th $I_{n}\left(w_{k}\right)$ values, e) PC map of 5th highest $I_{n}\left(w_{k}\right)$ values, f) PC map of 6 th $I_{n}\left(w_{k}\right)$ values

PCs were determined by Türkeș et al. (2002) and Türkeș (1998, 1999), whereas 8-year PC in the medium term and 16- and 17-year PCs in the long term have been added herein. The spring period is warm and indicates the time for the change in the seasonal environment of Turkey. During this period, unstable air types and events are experienced in Turkey; however, both midlatitude cyclones and hot air masses from the Sahara and the Arabian Peninsula have an influence. Furthermore, the effect of the Asian High is occasionally observed. As a result of these activities, the polar fronts are less drawn to the north, and the Azores High is expanded (Koçman 1993:4)

In summer, the frequency analysis of the PC between 2and 6-year PC was determined in several stations. A graph examination showed that a significant frequency followed the 12-year PC in the 11-year PC. A 21-year PC common throughout Turkey is also observed (Fig. 9). The analyses made by Türkeș et al. (2002) and Türkeș $(1998,1999)$ exhibited a short-term PC of only $2-5$ years in this season. The summer period expresses warm and arid conditions in Turkey; thus, polar air masses and the Asian High lose their effects (Erinç 1957, p. 129). Moreover, the hot air masses from the south, the Arabian Peninsula, and North Africa are more effective (Koçman 1993, p. 14), whereas these air masses mostly influence Turkey. The whole of Turkey is influenced by maritime polar air masses although their frequency decreases. Although the influence rate of these air masses varies from year to year, the hot air mass in the southeastern part of Turkey and the humid air mass on the Black Sea coasts are in effect.

The 2-, 3-, 4-, and 5-year PCs in the short term; 6-, 8-, and 9-year PCs in the medium term; and 13-, 14-, 17-, 19-, and 21year PCs in the long term are determined in various stations in autumn, as observed in Fig. 10, similar to the results obtained by Türkeș et al. (2002) and Türkeș (1998, 1999). In autumn, the temperatures began to decline, and the rainfall started to increase. During these periods, the effectiveness of midlatitude depression began to increase and became more effective 

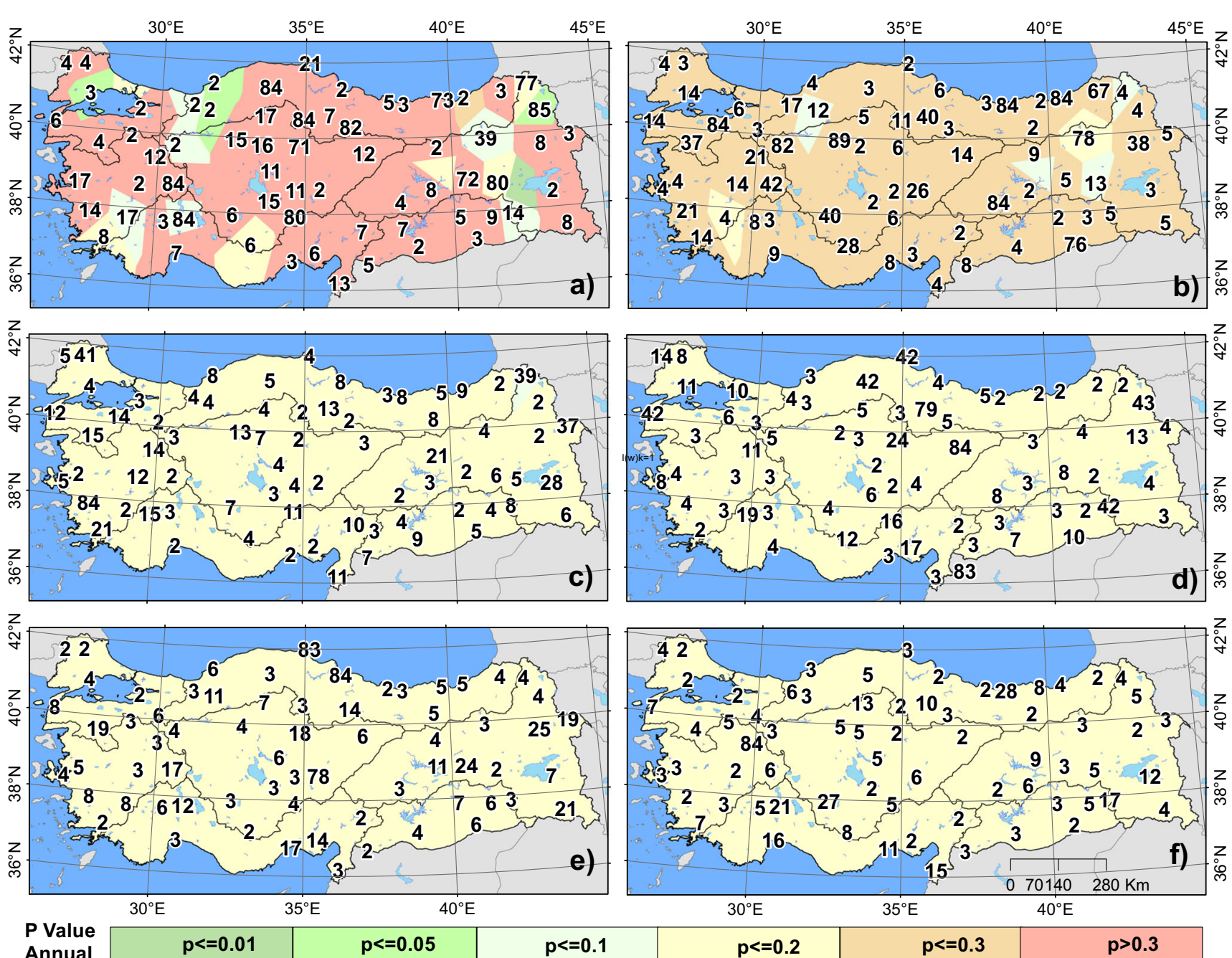

Fig. 6 a) PC map of highest $I_{n}\left(w_{k}\right)$ values, b) PC map of 2nd highest $I_{n}\left(w_{k}\right)$ values, c) PC map of 3rd highest $I_{n}\left(w_{k}\right)$ values, d) PC map of 4th $\mathrm{I}_{\mathrm{n}}\left(\mathrm{w}_{\mathrm{k}}\right)$ values, e) PC map of 5 th highest $\mathrm{I}_{\mathrm{n}}\left(\mathrm{w}_{\mathrm{k}}\right)$ values, f) PC map of 6 th $\mathrm{I}_{\mathrm{n}}\left(\mathrm{w}_{\mathrm{k}}\right)$ values

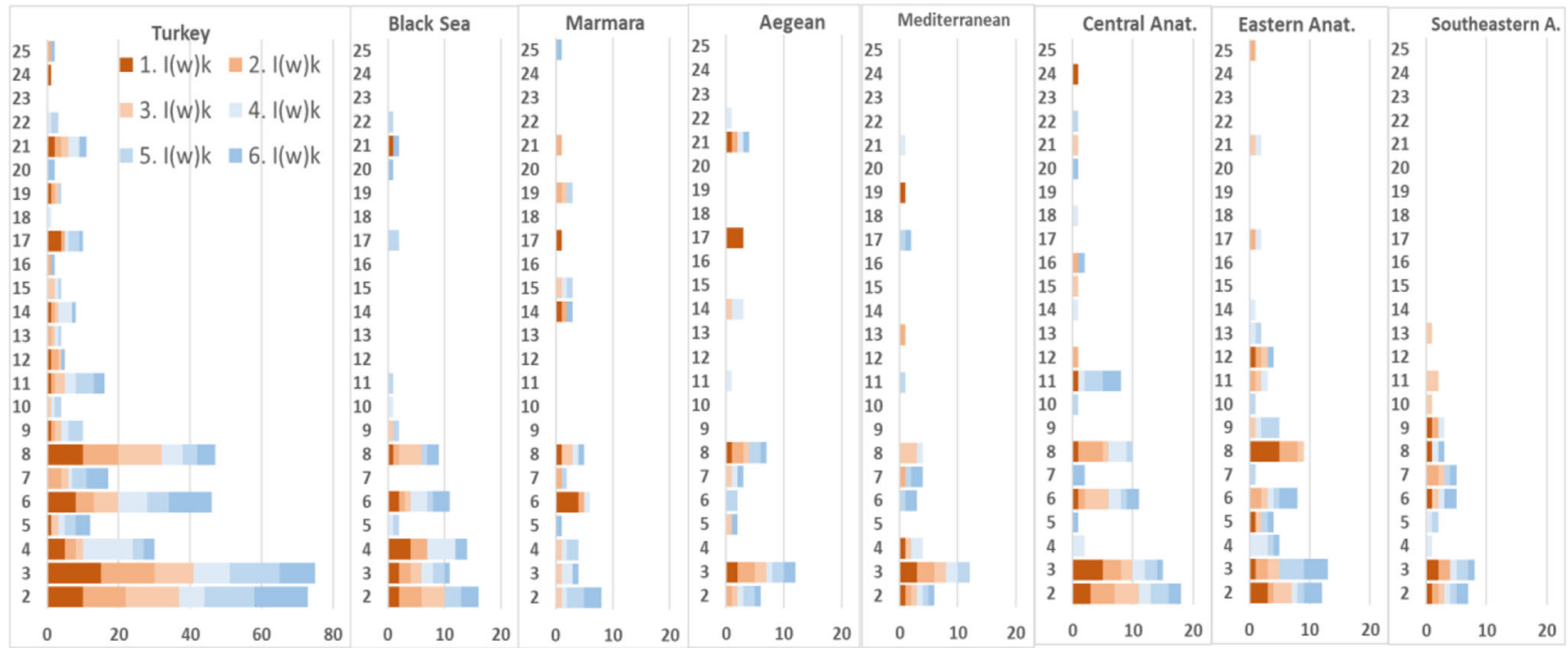

Fig. 7 Winter period length frequencies in Turkey by geographical regions based on the first six I(w) $k$ values. Periods of 26 and above are not shown here. The horizontal axis indicates the number of stations, whereas the vertical axis indicates periods 

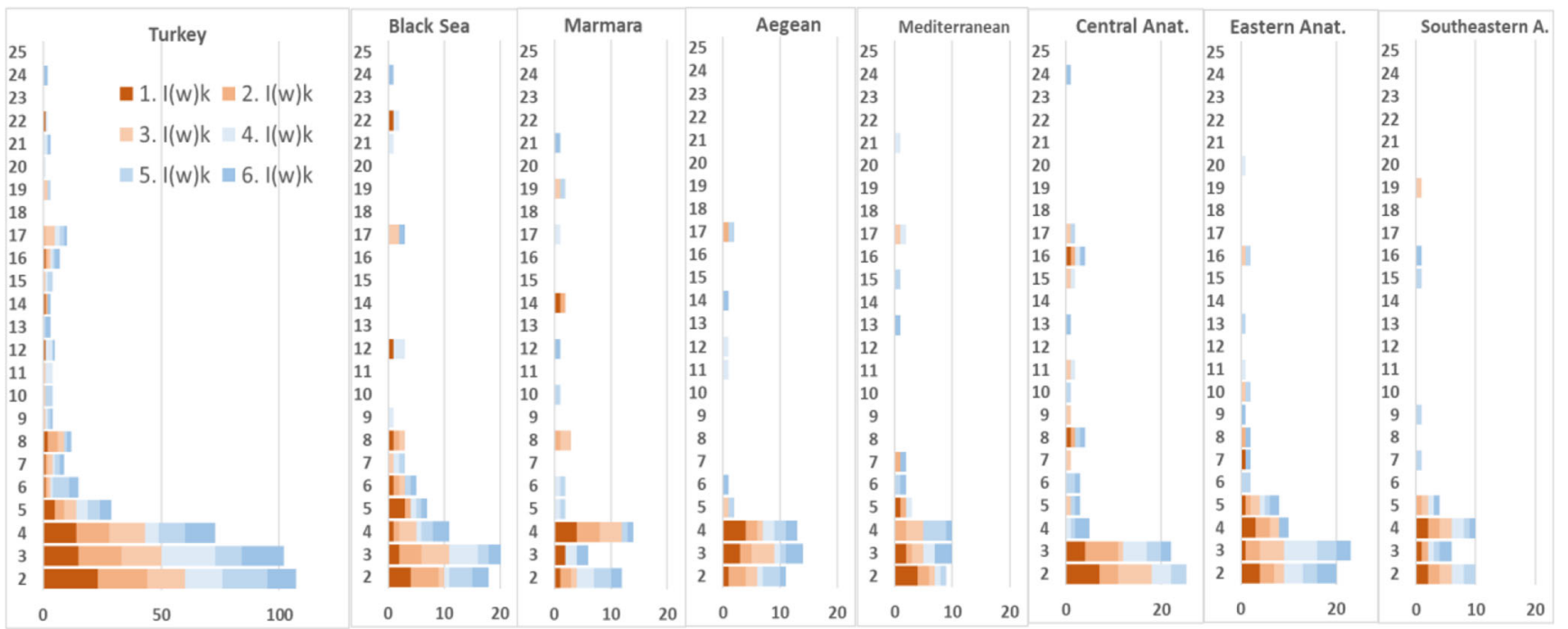

Fig. 8 Spring period length frequencies in Turkey by geographical regions based on the first six $\mathrm{I}(\mathrm{w}) k$ values. Axis properties are the same as those shown in Fig. 7

throughout Turkey (Erinç 1957, p. 129); however, the effect of the hot air mass from the south decreased toward the end of the season. The effect of the Asian High during this period was considerably limited.

The examination of the $\mathrm{PC}$ in annual total precipitation across Turkey shows 2-, 3-, 4-, and 5-year PCs during the short term; 6-, 7-, and 8-year PCs in the medium term; and 11-, 12-, 14-, 17-, and 21-year PCs in the long term (Fig. 11a). Moreover, the examination of all seasonal and annual PCs in Turkey exhibits 2-5-year PC in the short term; 6-8-year PC in the medium term; and 11-, 14-, 17-, and 21-year PCs in the long term, as presented in Fig. 11b.

The 2-year PC was frequently determined in the CAR, EAR, and SAR but rarely observed in the AR and MR (partly the MR). This cycle was more effective during the winters and springs in the CAR, summers in the EAR, and autumns in the SAR. The 2year cycle was more effective in Turkey's central and east part although the cycle was not evident around the Mediterranean and the Aegean Sea. The 2-year PC was determined in the Europe, Eastern Africa, Western Himalayas, China, and Niger rainfall series (Abdourahamane and Acar 2018; Brázdil et al. 1985; Hughes et al. 1994; Rodhe et al. 1976; Singh et al. 2006). This 2 -year cycle is said to be formed by the system that is effective in the Himalayas and other places. This system should be controlled by the quasibiennial oscillation, which is particularly dominant in the equatorial region.

The 3-year PC was frequently obtained in all seasons and regions, except for the Marmara during the winters. The system that creates this cycle must have affected the entirety of Turkey. From this perspective, a 3-year cycle was established

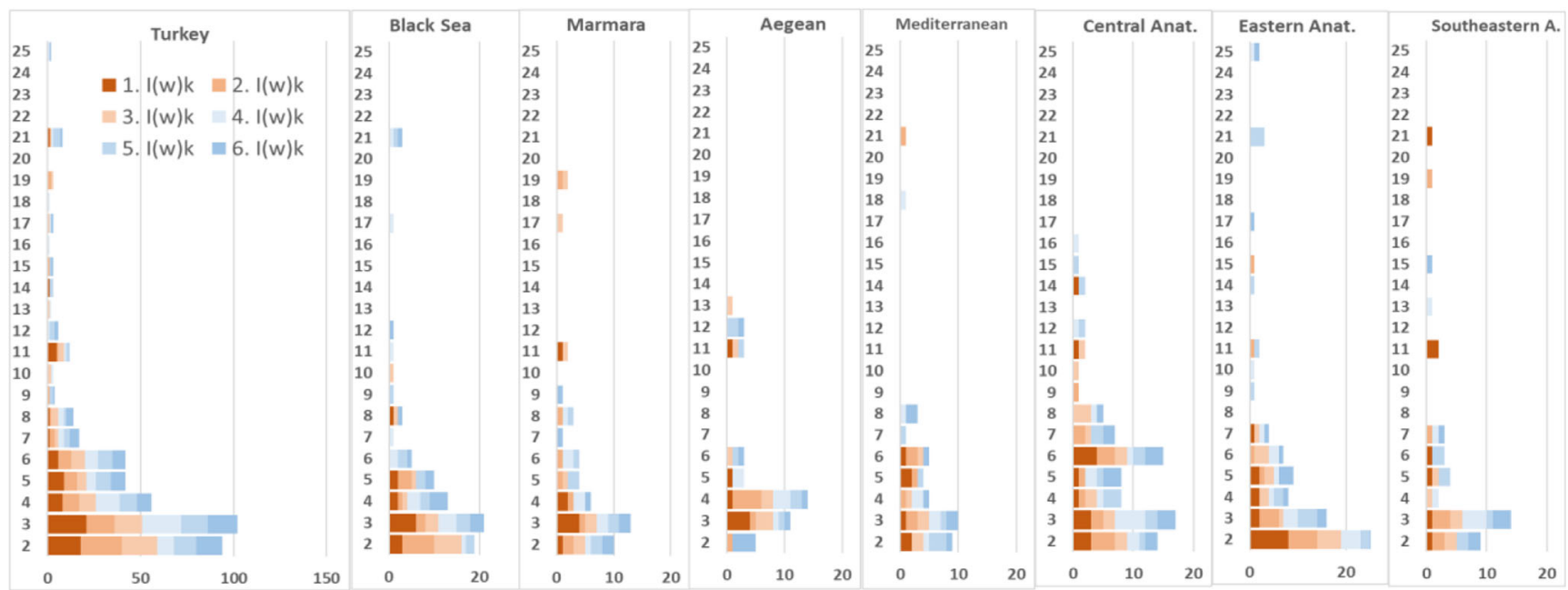

Fig. 9 Summer period length frequencies in Turkey by geographical regions based on the first six $\mathrm{I}(w) k$ values. Axis properties are the same as those shown in Fig. 7 


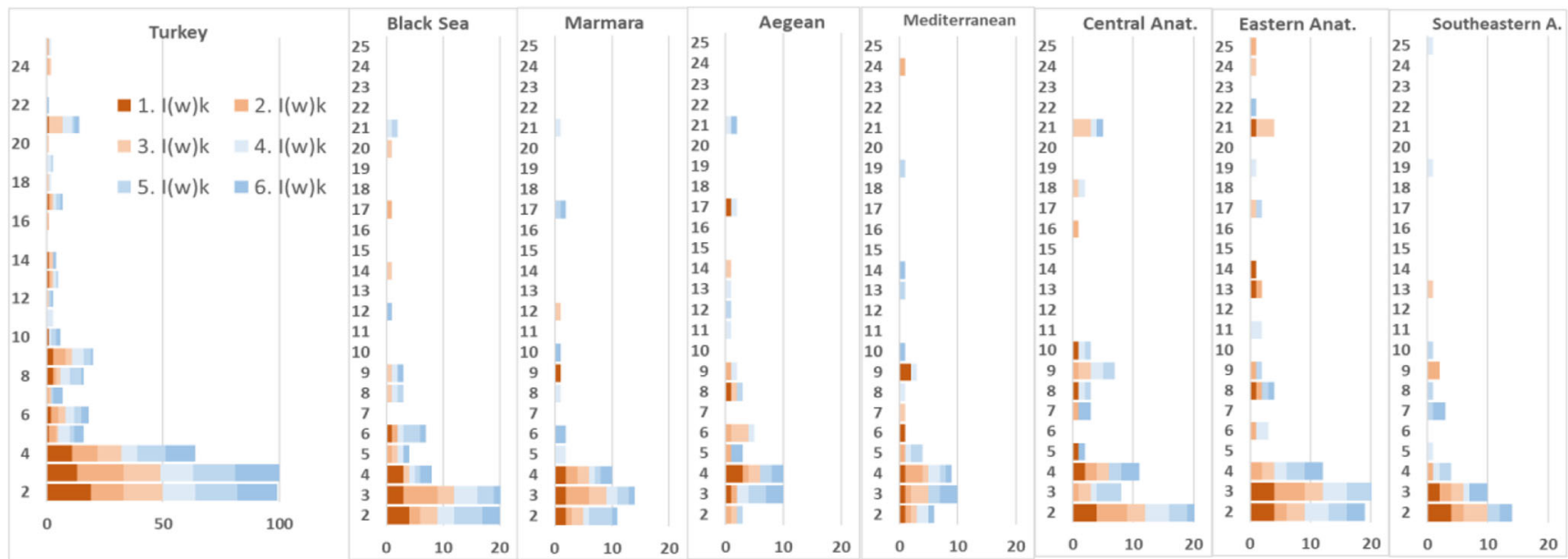

Fig. 10 Autumn period length frequencies in Turkey by geographical regions based on the first six $\mathrm{I}(w) k$ values. Axis properties are the same as those shown in Fig. 7
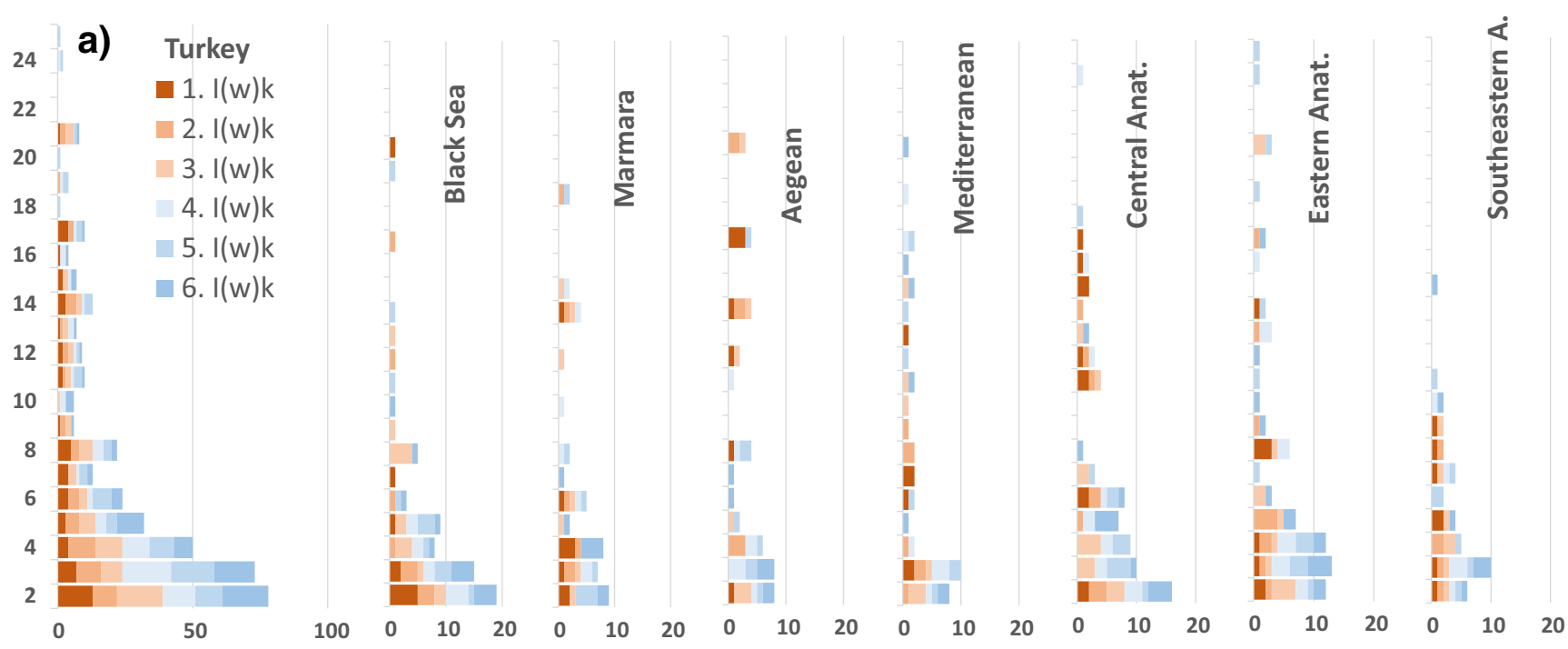

b) Turkey
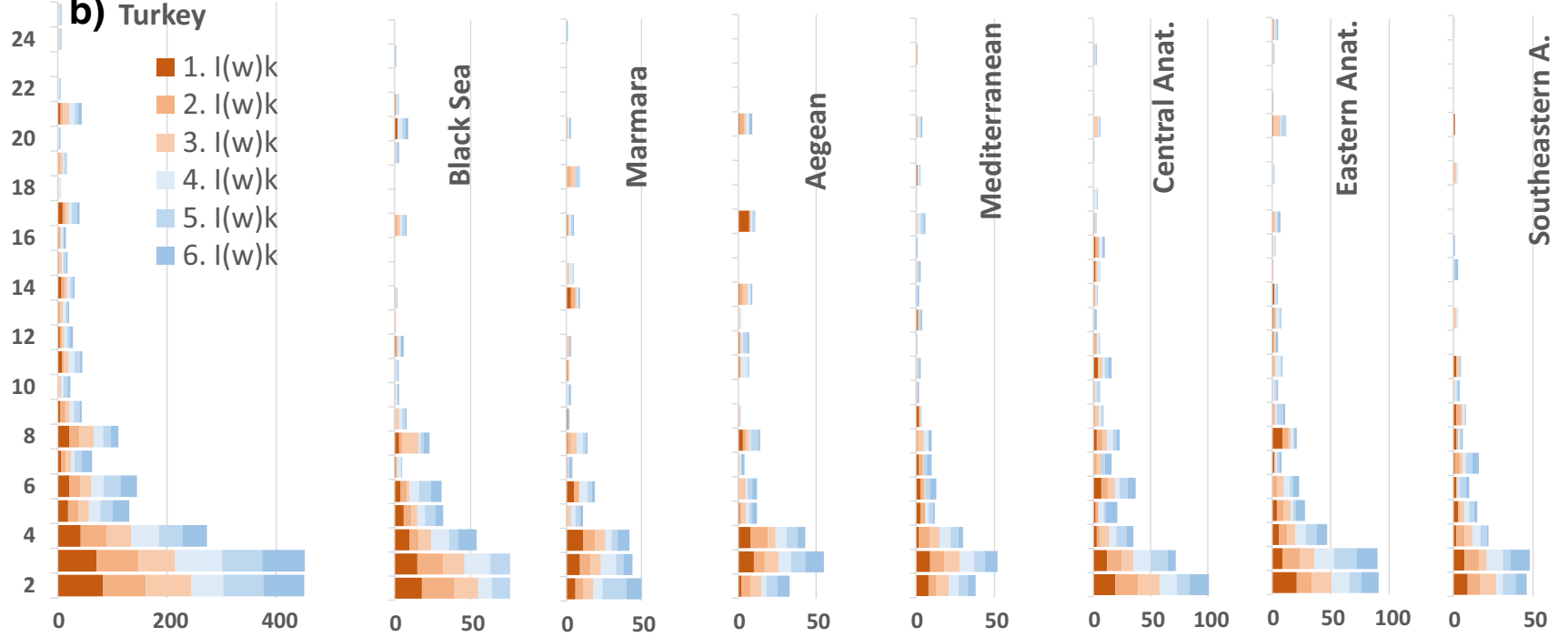

Fig. 11 Annual (a) and all seasons (b) period length frequencies in Turkey by geographical regions based on the first six I $(w) k$ values. Axis properties are the same as those shown in Fig. 7 
in the NAO and Europe precipitation series (Brázdil et al. 1985; Zhang et al. 2011) and arctic oscillation and North American precipitation series (Ashok et al. 2003; Hunt 2016).

The 4-year PC, which is more frequent in the BSR during the winters, was determined in the Aegean, Marmara, Mediterranean, and Southeastern Anatolia regions during the springs; AR in the summers; and Central Anatolia during the autumns. Therefore, the effect of the events that created this cycle varies depending on time and space. Meanwhile, a 4-year cycle was obtained in Europe (Brázdil et al. 1985) and North American precipitation series (Daniels 2007), extreme weather events in China (Vujović et al. 2018), and tree rings in Mongolia (Jacoby et al. 2003). This is associated with the events of ENSO in Central Asia (Jacoby et al. 2003). The definition of this cycle origin for Turkey is rather complex, and both equatorial (ENSO) and polar systems (NAO) exhibit these cycles.

The 5-year PC was formed in Eastern Anatolia during the winters; Black Sea, Eastern, and Southeastern Anatolia in the springs; Eastern and Southeastern Anatolia and the BSR in the summers; and Aegean and Mediterranean regions in the autumns although its frequency was not at a sufficient level compared to the other cycles. The PC was also frequent in the Black Sea, Central, Eastern, and Southeastern Anatolia regions at their annual precipitation series. The European and East African precipitation series exhibited 5-year cycles (Brázdil et al. 1985; Rodhe et al. 1976), which were also found in China and Korea (Kim and Byun 2010; Luan et al. 2009).

The 6-year PC is more frequent in all regions except the Aegean and Mediterranean regions in the winters, the BSR in the springs, the Central and Eastern Anatolian regions in the summers, the Black Sea and ARs during the autumns, and the Aegean and Central Anatolia regions in the annual total precipitation series. This cycle has been identified in the Iberian Peninsula (Merino et al. 2015) and Central China (Tan et al. 2009) and may be related to NAO and ENSO. This cycle may occur at a place connected with teleconnections.

While the described annual precipitation in the Southeastern and Central Anatolia, Southeastern Anatolian in the winters, and Central Anatolian in the summer precipitation, the 7-year PC was only slightly effective in all seasons and regions. The 7-year PC was also determined in the zooplankton density series at the Adriatic Sea (Baranovic et al. 1993), current precipitation series in North America (Daniels 2007), and tree rings growth sequences in China (Hughes et al. 1994).

In general, the 8-year PC is more frequent in annual precipitation than in short-term cycles. It was determined in all regions, except for the Southeastern and Mediterranean regions during the winters. It was more frequently found in Central Anatolia during summers and autumns, and its frequency decreased in the springs. These cycles have also been identified in Italy and North African precipitation series (Brunetti et al. 2000; McHugh and Rogers 2001) and the NAO index (Brázdil et al. 1985). The cycle, which particularly affects the southern region of Turkey, must be associated with NAO. Midlatitude depression can hit the south of the Mediterranean during times when NAO is negative (during winters) and can obtain moisture from the Mediterranean. The southern part of Turkey observes more precipitation during these periods.

Conversely, the 9-year cycles are more frequently seen in Eastern Anatolia during the winter period and Central Anatolia in the autumns and are very rare in other seasons and regions. This cycle was determined in varve sediments in the Mediterranean (Manzi et al. 2012) and during the series of precipitation and tree rings in China (Hughes et al. 1994; Luan et al. 2009). The presence of loop only in winters and autumns supports both the Eastern and Central Anatolia regions, which can be managed by a system affecting China, suggesting the Asian High.

The 11-year PC that is likely to be associated with solar activities (Arlt 2011; Hathaway 2015) is also seen in the Turkey precipitation series. This cycle became more frequent in the Central, Eastern, and Southeastern Anatolia regions, with more terrestrial characteristics. The 11-year PC frequency, particularly in the winter season, is fundamental. In the AR with marine conditions, this cycle was determined during the summers. Hence, it was not only seen in terrestrial areas but also in all regions. Terrestrial lands are affected by all seasons; however, marine regions are only affected during the summers. Therefore, it must be associated with other events. Some other patterns and connections (e.g., NAO, North Sea Caspian) probably mask this cycle, causing a faint effect.

The 14-year PC has become more frequent during annual and winter precipitations in the Marmara and Aegean regions and are rarely seen in the other periods. These regions represent the areas where the midlatitude depression from the Balkans first took effect. The 14-year cycles have also been determined in the Italy precipitation series (Brunetti et al. 2000), southern oscillations index (Luo and Yamagata 2001), climatic events in central China (Tan et al. 2009), and Korea (Kim and Byun 2010). These cycles are believed to be associated with NAO caused by the annual cycles of seven $(14: 2=7)$. The 7-year cycles must exhibit strong and weak periods, affecting more places in periods of strength time. As will be mentioned below, 21-year cycles should also be a repetition of this cycle.

The 17-year PC was determined only in the Aegean Region in the winters and annual precipitation series, only in the BSR during the summer, and was obtained (e.g., Türkeş et al. (2002)), as 18-year PC in other studies. Although the 17year PC is an unprecedented cycle in the literature, it can be a half-period of 34-35 years $(34: 2=17)$.

The 21-year PC is often found in the Aegean, Black Sea, and Eastern Anatolia regions in winter and Central and Eastern Anatolian regions in autumn. Nothing indicates that this cycle is a $3 \times 7$-year cycle or a 22-year cycle resulting from solar activity. However, a $7 \times 3$-year cycle is believed to be strengthened by solar activities. 

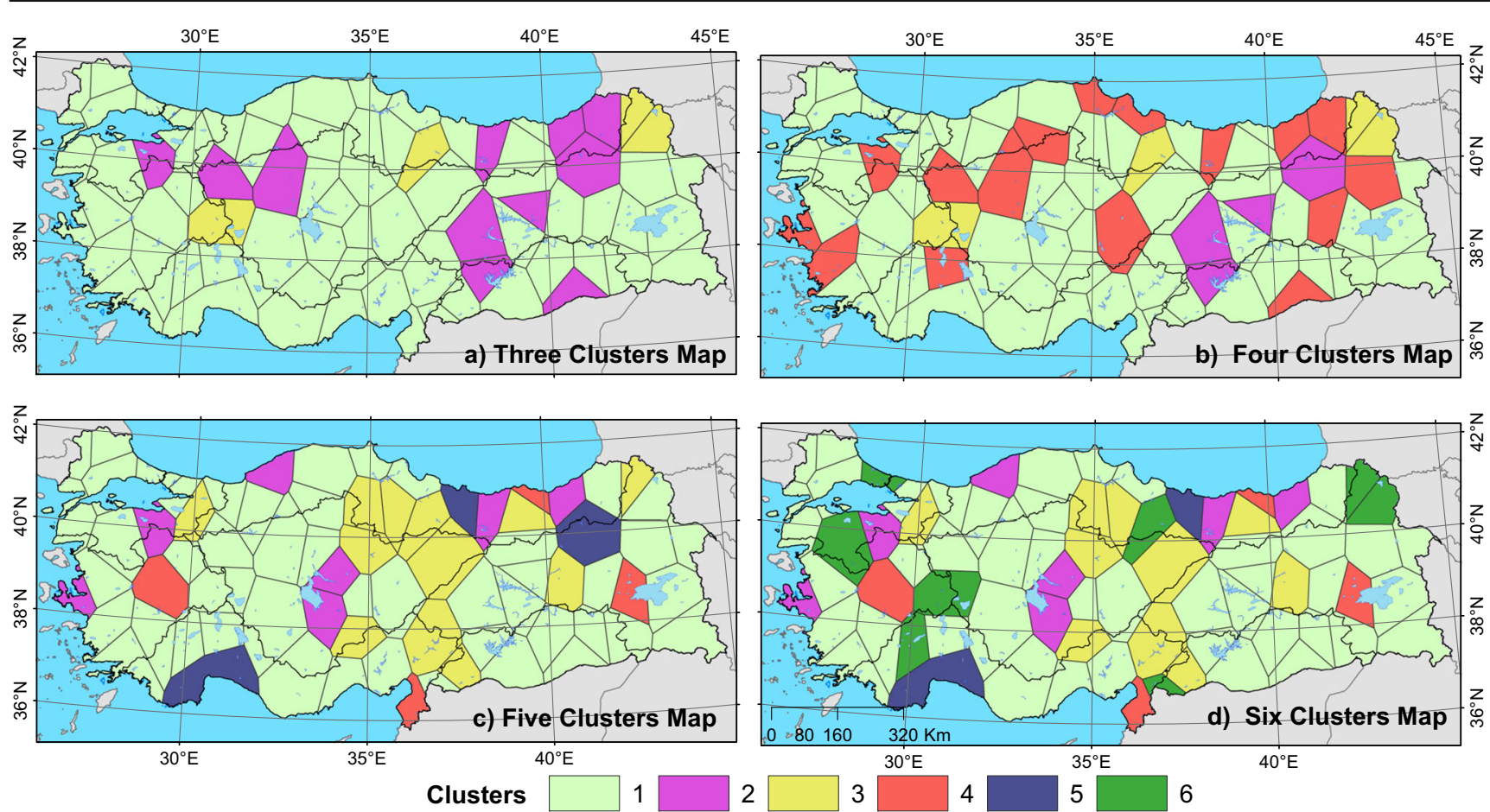

Fig. 12 a) Three cluster map, b) Four cluster map c) Five cluster map, d) Six cluster map

Similarities of the cycle lengths identified in Turkey and in other parts of the world are believed to be attributed to the same mechanisms affecting different fields. While short-term cycles exist in the whole of Turkey, medium- and long-term cycles vary according to the region and season. Cluster analysis was done and repeated using 3-6 clusters with the first cluster obtained in many stations. All four cluster analyses are shown in Fig. 12. For three clusters analysis, different groups were formed in EAR, CAR, SAR, and BSR, while a new cluster was obtained in the same regions using four clusters analysis. The second cluster obtained in the three clusters analysis was also determined in EAR using the four clusters analysis.

When five clusters were used to analyze the cycles, the first cluster covered a large part of Turkey. The second cluster was obtained in CAR and the Black Sea coast, whereas the third cluster was defined in the borders of CAR, BSR, and eastern MR. The fourth and fifth clusters were obtained in areas far from each other. When six clusters were used to repeat the analysis, the second and third clusters were determined in similar places, whereas the fourth and fifth clusters were formed in unrelated places. The sixth cluster has been defined in MAR, east of AR, and in northeast of Turkey.

When the clusters are evaluated, the short-term cycles are determined throughout Turkey forming the first PC region. The second PC region is covered in EAR, CAR, BSR, and east of AR, while the third PC region is defined as the borders of CAR and east of MR. The clusters that emerged in different and unrelated fields occurred by local effects.

Table 2 Dominant PC in the geographical regions of Turkey

\begin{tabular}{|c|c|c|c|c|}
\hline Geographical region & Spring & Summer & Autumn & Winter \\
\hline Black Sea & $\begin{array}{l}2,3,4,5,6,7,8,12,17 \\
\text { and } 22\end{array}$ & $2,3,4,5,6,8$, and 21 & $2,3,4,6,8,9,17$, and 21 & $2,3,4,6,8,17$, and 21 \\
\hline Marmara & $2,3,4,8$, and 14 & $2,3,4,5,6,8,11$, and 19 & $2,3,4$, and 17 & $\begin{array}{l}2,3,4,6,8,14,15,17 \\
\quad \text { and } 19\end{array}$ \\
\hline Aegean & 2,3 , and 4 & $3,4,11$, and 12 & $3,4,6,8,9,17$, and 21 & $2,3,8,17$, and 21 \\
\hline Mediterranean & 2,3 , and 4 & $2,3,4,5,6,8$, and 21 & $2,3,4,5$, and 9 & $2,3,4,7,8,17$, and 19 \\
\hline Central Anatolian & $2,3,8$, and 16 & $\begin{array}{l}2,3,4,5,6,7,8,11,12 \\
\quad \text { and } 14\end{array}$ & $2,3,4,7,8,9,18$, and 21 & $2,3,6,8,11$, and 16 \\
\hline Eastern Anatolian & $2,3,4$, and 5 & $2,3,4,5,6,7$, and 21 & $2,3,4,6,8,13,17$, and 21 & $\begin{array}{l}2,3,4,6,8,9,11,12,17 \\
\text { and } 21\end{array}$ \\
\hline Southeastern Anatolian & $2,3,4$, and 5 & $2,3,5$, and 6 & $2,3,4,7,9,13$, and 19 & $2,3,6,7,8,9,11$, and 13 \\
\hline
\end{tabular}




\section{Conclusion}

Monthly precipitation data from 74 stations in Turkey (19262018) was used for examining seasonal and annual cycles of rainfall. Although the periodicity of rainfall data in Turkey has previously been studied, which included 54-65 years of data, this study suggests an alternative approach (i.e., periodogram) for applying the analysis to data of longer periods (56-84 years). This study also shows the six most prominent cycles in all stations, including cycle frequency graphs created by the annual and seasonal rainfall data. Cycles were graphically studied before they were mapped in the present analysis. The spatial distribution of cycles was determined, and regions with similar precipitation cycles were defined. Moreover, new cycles were obtained. The acquired results and observations are presented below.

Turkey has 2-, 3-, 6-, 8-, 11-, 14-, 17-, and 21-year PCs in the winters; 2-4-, 8-, 16-, and 17-year PCs in the springs; 2-6-, 11-, 12-, and 17-year PCs in the summers; 2-9-, 13-, 14-, 17-, 19-year PCs in the autumns; and 2-8-, 11-, 12-, 14-, 17-, and 21-year PCs in the annual precipitation series. The seasonal cycles vary based on the regions, as shown in Table 2.

Table 2 shows that Turkey's seasonal and annual cycles do not exactly overlap in the spatial scale. Each cycle does not repeat in all seasons. The regional differences generally compose a season; however, nearby regions show similar cycles. This result indicates that the air masses and pressure structures in Turkey exhibit different regional effects. Moreover, oscillations, patterns, and teleconnections have different impacts. This situation has been observed in the same season although different regions are represented by different cycles.

The dominant 11- and 3-year PCs were determined throughout Turkey. This implies that cycles originating from sunspot activities and NAO have an impact across Turkey.

Cluster analysis was applied to the length of PC and the three PC regions are defined as: (1) across the Turkey; (2) EAR, CAR, BSR, and east of AR; and 3) borders of CAR and the east of MR. A fourth region wherein local factors are effective was formed in areas far from each other.

Analyzed time series can be modeled for forecasting although the cycles obtained have low significancy. For this purpose, multiple regressions must be used, and parameters (regression coefficient) for each cycle should be determined. Cycles with insignificant parameters can be removed from the model with the rest of the parameters still sufficient for modeling.

The result of the period lengths had some mathematical similarities. If any $\boldsymbol{f}$ function defined on the real numbers provides $\boldsymbol{f}(\boldsymbol{x}+\boldsymbol{P})=\boldsymbol{f}(\boldsymbol{x}), \boldsymbol{f}$ is called a periodic function for all $x \in R$ s, and $p$ is the period of the function. It is easy to see if the $f$ period is a periodic function of $p, f(x+2 p)=f((x+p)+$ $p)=f(x+P)=f(x)$ is the period of the same function in all multiples of $\boldsymbol{p}$. Accordingly, many periods of a function can be found. The smallest of these periods is called the main period of the function (Altın 2011, p. 4). Consecutive values, such as
7-14-21, were obtained from the analysis. These cycles are essentially a single cycle; however, the other events are more effective when the cycle does not gain a dominant character and can be masked during a non-dominant period.

The cycle lengths obtained in the Turkey precipitation series were similar to those in the literature while comparing other places throughout the earth. These similarities between outlying areas show that the system creating these cycles affects these areas in the same or opposite manner, suggesting a teleconnection between these areas.

The cycle lengths obtained via the periodogram analysis and the values obtained via the spectrum analysis and the autocorrelations overlapped. The periodograms are suitable for use in analyzing the climatic time series for the determination of cycles.

\section{Authors' contributions Conceptualization: Erkan Yilmaz \\ Methodology: Yilmaz Akdi \\ Formal analysis and investigation: Y1lmaz Akdi \\ Writing-original draft preparation: Erkan Yılmaz \\ Data Curation: Esra Uğuca \\ Proofreading: İhsan Ciçek, Cemal Atakan}

Data availability The datasets used and/or analyzed during the current study are available from the corresponding author on reasonable request.

\section{Compliance with ethical standards}

Competing interests The authors declare that they have no competing interest.

\section{Ethics approval and consent to participate Not applicable}

\section{Consent for publication Not applicable}

Open Access This article is licensed under a Creative Commons Attribution 4.0 International License, which permits use, sharing, adaptation, distribution and reproduction in any medium or format, as long as you give appropriate credit to the original author(s) and the source, provide a link to the Creative Commons licence, and indicate if changes were made. The images or other third party material in this article are included in the article's Creative Commons licence, unless indicated otherwise in a credit line to the material. If material is not included in the article's Creative Commons licence and your intended use is not permitted by statutory regulation or exceeds the permitted use, you will need to obtain permission directly from the copyright holder. To view a copy of this licence, visit http://creativecommons.org/licenses/by/4.0/.

\section{References}

Abdourahamane ZS, Acar R (2018) Analysis of meteorological drought variability in Niger and its connection with climate indices. Hydrol Sci J 63(8):1203-1218. https://doi.org/10.1080/02626667.2018. 1489542

Afzal M, Gagnon AS, Mansell MG (2014) Changes in the variability and periodicity of precipitation in Scotland. Theor Appl Climatol 119(12):135-159. https://doi.org/10.1007/s00704-014-1094-2 
Akdi Y, Dickey DA (1998) Periodograms of unit root time series: distributions and tests. Commun Stat Theory Methods 27(1):69-87. https://doi.org/10.1080/03610929808832651

Altın A (2011) Fournier Analysis. Gazi Press, Ankara

Arlt R (2011) The sunspot observations by Samuel Heinrich Schwabe. Astronomische Nachr 332(8):805-814. https://doi.org/10.1002/ asna.201111601

Ashok K, Guan Z, Yamagata T (2003) A look at the relationship between the ENSO and the Indian Ocean Dipole. J Meteorol Soc Jpn 81(1): 41-56. https://doi.org/10.2151/jmsj.81.41

Asong ZE, Wheater HS, Bonsal B, Razavi S, Kurkute S (2018) Historical drought patterns over Canada and their teleconnections with largescale climate signals. Hydrol Earth Syst Sci 22(6):3105-3124. https://doi.org/10.5194/hess-22-3105-2018

Baldwin MP, Gray LJ, Dunkerton TJ, Hamilton K, Haynes PH, Randel WJ, Holton JR, Alexander MJ, Hirota I, Horinouchi T, Jones DBA, Kinnersley JS, Marquardt C, Sato K, Takahashi M (2001) The quasi-biennial oscillation. Rev Geophys 39(2):179-229. https:// doi.org/10.1029/1999RG000073

Baranovic A, Solic M, Vucetic T, Krstulovic N (1993) Temporal fluctuations of zooplankton and bacteria in the middle Adriatic Sea. Mar Ecol Prog Ser 92:65-75. https://doi.org/10.3354/meps092065

Brázdil R, Samaj F, Valoviĉ (1985) Variation of spatial annual precipitation sums in central europe in the period 1881-1980. J Climatol 5(6): 617-631. https://doi.org/10.1002/joc.3370050604

Brázdil R, Trnka M, Dobrovolný P, Chromá K, Hlavinka P, Zcaron;alud, Z. (2009) Variability of droughts in the Czech Republic, 1881-2006. Theor Appl Climatol 97(3-4):297-315. https://doi.org/10.1007/ s00704-008-0065-x

Brockwell PJ, Davis RA (1987) Time Series: theory and Methods. Springer-Verlag

Brunetti M, Maugeri M, Nanni T (2000) Variations of temperature and precipitation in Italy from 1866 to 1995 . Theor Appl Climatol 65(34):165-174. https://doi.org/10.1007/s007040070041

Bush MB, Hansen BCS, Rodbell DT, Seltzer GO, Young KR, León B, Abbott MB, Silman MR, Gosling WD (2005) A 17 000-year history of Andean climate and vegetation change from Laguna de Chochos, Peru. J Quat Sci 20:703-714. https://doi.org/10.1002/jqs.983

Daniels JM (2007) Flood hydrology of the North Platte River headwaters in relation to precipitation variability. J Hydrol 344(1-2):70-81. https://doi.org/10.1016/j.jhydrol.2007.06.020

Davies A, Kemp AES, Weedon GP, Barron JA (2012) El Niño-Southern oscillation variability from the late cretaceous marca shale of california. Geology 40(1):15-18. https://doi.org/10.1130/G32329.1

Enders CK (2010) Summary for Policymakers. In: Applied missing data analysis. The Guilford Press, London. https://doi.org/10.1017/ CBO9781107415324.004

Erinç S (1957) Tatbiki Klimatoloji ve Türkiye’nin İklim Şartları (Applied Climatology and Climate Conditions in Turkey). Istanbul Tecnical University Press, Istanbul

Fairbridge R, Erol O, Karaca M, Yilmaz Y (1997) Background to MidHolocene climatic change in Anatolia and adjacent regions. In: Third Millennium BC Climate Change and Old World Collapse. Springer Berlin Heidelberg, Berlin, pp 595-610. https://doi.org/10. 1007/978-3-642-60616-8 26

Fang Y, Qian H, Chen J, Xu H (2018) Characteristics of spatial-temporal evolution of meteorological drought in the Ningxia Hui autonomous region of northwest China. Water (Switzerland) 10(8). https://doi. org/10.3390/w10080992

Fuller WA (1996) Introduction to statistical time series. Wiley

Gajic-Capka M (1992) Stationarity, trend and periodicity of precipitation at the Zagreb- Gric Observatory from 1862 to 1990 . Croat Meteorol J 27:1-10

Gajić-Čapka M (1994) Periodicity of annual precipitation in different climate regions of Croatia. Theor Appl Climatol 49(4):213-216. https://doi.org/10.1007/BF00867460
Guo H, Bao A, Liu T, Jiapaer G, Ndayisaba F, Jiang L et al (2018) Spatial and temporal characteristics of droughts in Central Asia during 1966-2015. Sci Total Environ 624:1523-1538. https://doi.org/10. 1016/J.SCITOTENV.2017.12.120

Hathaway DH (2015) The solar cycle. Living Rev Solar Phys 12(1):4. https://doi.org/10.1007/lrsp-2015-4

Hodell DA, Brenner M, Curtis JH, Guilderson T (2001) Solar forcing of drought frequency in the Maya lowlands

Hughes MK, Xiangding W, Xuemei S, Garfin GM (1994) A preliminary reconstruction of rainfall in north-central china since a.d. 1600 from tree-ring density and width. Quat Res 42(1):88-99. https://doi.org/ 10.1006/qres.1994.1056

Hunt BG (2016) Rainfall variability and predictability issues for North America. Clim Dyn 46(7-8):2067-2085. https://doi.org/10.1007/ s00382-015-2690-2

Jacoby G, Pederson N, D'Arrigo R (2003) Temperature and precipitation in Mongolia based on dendroclimatic investigations. Chin Sci Bull 48:1474-1479. https://doi.org/10.1360/02wd0390

Jin D, Kirtman BP (2010) The impact of ENSO periodicity on North Pacific SST variability. Clim Dyn 34(7):1015-1039. https://doi. org/10.1007/s00382-009-0619-3

Kerr RA (1987) Milankovitch Climate Cycles Through the Ages. Science 235(4792):973 LP-973974

Kim DW, Byun HR (2010) Spatiotemporal characteristics and assessment of historical drought in Korea. Options Méditerranéennes. Séries A. Mediterranean Seminars, (95), 101-105

Koçman A (1993) Climate of Turkey. Aegean University Press, İzmir

Lázaro R, Rodrigo FS, Gutiérrez L, Domingo F, Puigdefábregas J (2001) Analysis of a 30-year rainfall record (1967-1997) in semi-arid SE spain for implications on vegetation. J Arid Environ 48(3):373-395. https://doi.org/10.1006/jare.2000.0755

Lean J, Rind D (1998) Climate forcing by changing solar radiation. J Clim 11. https://doi.org/10.1175/1520-0442(1998)011<3069: CFBCSR $>2.0 . \mathrm{CO} ; 2$

Luan Q, Yuan J, Guo Z, Shi B (2009) Analyzing the periodicity and trend of precipitation with multi-resolution analysis in mountain regions of Handan, China. PEITS 2009 - 2009 2nd Conference on Power Electronics and Intelligent Transportation System in (Vol. 3, pp. 85-88). IEEE. https://doi.org/10.1109/PEITS.2009.5406900

Luo J-J, Yamagata T (2001) Long-term El Niño-Southern Oscillation (ENSO)-like variation with special emphasis on the South Pacific. J Geophys Res Oceans 106(C10):22211-22227. https://doi.org/10. 1029/2000JC000471

Manly BFJ (2004) Multivariate statistical methods, 3rd edn. Taylor \& Francis, New York

Manzi V, Gennari R, Lugli S, Roveri M, Scafetta N, Schreiber BC (2012) High-frequency cyclicity in the mediterranean Messinian evaporites: evidence for solar-lunar climate forcing. J Sediment Res 82(12):991-1005. https://doi.org/10.2110/jsr.2012.81

Mccabe-Glynn S, Johnson KR, Strong C, Berkelhammer M, Sinha A, Cheng H, Edwards RL (2013) Variable North Pacific influence on drought in southwestern North America since AD 854. Nat Geosci 6(8):617-621. https://doi.org/10.1038/ngeo1862

McHugh MJ, Rogers JC (2001) North Atlantic oscillation influence on precipitation variability around the Southeast African convergence zone. J Clim 14(17):3631-3642. https://doi.org/10.1175/15200442(2001)014<3631:NAOIOP>2.0.CO;2

Merino A, López L, Hermida L, Sánchez JL, García-Ortega E, Gascón E, Fernández-González S (2015) Identification of drought phases in a 110-year record from Western Mediterranean basin: trends, anomalies and periodicity analysis for Iberian Peninsula. Glob Planet Chang 133:96-108. https://doi.org/10.1016/j.gloplacha.2015.08. 007

Muller RA, Macdonald GJ (1997) Spectrum of 100-kyr glacial cycle: orbital inclination, not eccentricity, 94, 8329-8334 
Mursula K, Usoskin IG, Kovaltsov GA (2002) A 22-year cycle in sunspot activity. Adv Space Res 29(12):1979-1984. https://doi.org/10.1016/ S0273-1177(02)00244-2

Okkaoğlu Y, Akdi Y, Ünlü KD (2020) Daily PM10, periodicity and harmonic regression model: the case of London. Atmos Environ 238(2020): 117755

Pascoe CL, Gray LJ, Crooks SA, Juckes MN, Baldwin MP (2005) The quasi-biennial oscillation: analysis using ERA-40 data. J Geophys Res D Atmos 110(8):1-13. https://doi.org/10.1029/2004JD004941

Polonskii AB, Basharin DV, Voskresenskaya EN, Worley S (2004) North Atlantic oscillation: description, mechanisms, and influence on the eurasian climate. Phys Oceanogr 14:96-113. https://doi.org/ 10.1023/B:POCE.0000037873.85289.6e

Rial JA (2004) Earth's orbital eccentricity and the rhythm of the Pleistocene ice ages: the concealed pacemaker. Glob Planet Chang 41(2):81-93. https://doi.org/10.1016/j.gloplacha.2003.10.003

Rodhe H, Virji H, Rodhe H, Virji H (1976) Trends and periodicities in East African rainfall data. Mon Weather Rev 104(3):307-315. https://doi.org/10.1175/1520-0493(1976)104<0307:TAPIEA>2.0. $\mathrm{CO} ; 2$

Singh J, Park WK, Yadav RR (2006) Tree-ring-based hydrological records for western Himalaya, India, since A.D. 1560. Clim Dyn 26(2-3):295-303. https://doi.org/10.1007/s00382-005-0089-1

Stager JC, Cumming BF, Laird KR, Garrigan-Piela A, Pederson N, Wiltse B, Lane CS, Nester J, Ruzmaikin A (2017) A 1600-year diatom record of hydroclimate variability from Wolf Lake, New York. Holocene 27(2):246-257. https://doi.org/10.1177/ 0959683616658527

Strikis NM, Cruz FW, Cheng H, Karmann I, Edwards RL, Vuille M, Wang X, de Paula MS, Novello VF, Auler AS (2011) Abrupt variations in South American monsoon rainfall during the Holocene based on a speleothem record from central-eastern Brazil. Geology 39(11):1075-1078. https://doi.org/10.1130/G32098.1

Tan L, Cai Y, Cheng H, An Z, Edwards RL (2009) Summer monsoon precipitation variations in central China over the past 750 years derived from a high-resolution absolute-dated stalagmite.
Palaeogeogr Palaeoclimatol Palaeoecol 280(3-4):432-439. https:// doi.org/10.1016/j.palaeo.2009.06.030

Türkeș M (1998) Influence of geopotential heights, cyclone frequency and Southern oscillation on rainfall variations in Turkey. Int $\mathrm{J}$ Climatol 18(6):649-680. https://doi.org/10.1002/(SICI)10970088(199805)18:6<649::AID-JOC269>3.0.CO;2-3

Türkeş M (1999) Vulnerability of Turkey to desertification with respect to precipitation and aridity conditions. Turk J Eng Environ Sci 23(5):363-380

Türkeș M (2010) General Climatology. Ertem Büro Press, Ankara

Türkeș M, Sümer UM, Kiliç G (2002) Persistence and periodicity in the precipitation series of Turkey and. Clim Res 21(1):59-81. https:// doi.org/10.3354/cr021059

van den Heuvel EPJ (1966) On the precession as a cause of Pleistocene variations of the Atlantic Ocean water temperatures. Geophys J R Astron Soc 11(3):323-336. https://doi.org/10.1111/j.1365-246X. 1966.tb03086.x

Vujović D, Todorović N, Paskota M (2018) Summer weather characteristics and periodicity observed over the period 1888-2013 in the region of Belgrade, Serbia. Theor Appl Climatol 132(1-2):103114. https://doi.org/10.1007/s00704-017-2075-z

Wang L, Samthein M, Erlenkeuser H, Grootes PM, Grimalt JO, Pelejero C, Linck G (1999) Holocene variations in Asian monsoon moisture: a bidecadal sediment record from the South China Sea. 26. https:// doi.org/10.1029/1999GL900443

Wei WWS (2006) Time series analysis univariate and multivariate methods. Pearson Education, 2nd edn. Pearson Addison Wesley, Boston. https://doi.org/10.1016/0169-2070(91)90015-N

Zhang XJ, Jin LY, Chen CZ, Guan DS, Li MZ (2011) Interannual and interdecadal variations in the North Atlantic Oscillation spatial shift. Chin Sci Bull 56(24):2621-2627. https://doi.org/10.1007/s11434$011-4607-8$

Publisher's note Springer Nature remains neutral with regard to jurisdictional claims in published maps and institutional affiliations. 